\title{
EUROPEAN UNION LEGAL PROVISIONS ON THE ADMISSION OF THIRD- COUNTRY NATIONALS FOR THE PURPOSE OF EMPLOYMENTAS SEASONAL WORKERS
}

\author{
E.-N. VÂLCU
}

\section{ELISE-NICOLETA VÂLCU}

University of Pitești, Pitești, Romania

E-mail: elisevalcu@yahoo.com

\begin{abstract}
"The global approach in matters of migration and mobility", adopted by the Commission in 2011, sets out a general framework for the relations of the European Union with the third countries in matters of migration. This approach is based on four pillars: legal immigration and mobility, illegal immigration and human trafficking, international protection and asylum policy, as well as maximization of the impact of migration and of mobility on development.

On 13th May 2015, the Commission presented"The European Agenda on migration" proposing immediate measures and actions to perform in the following years for a better management of migration under all its aspects. Within it, the Commission proposes orientations in four directions: reduction of factors encouraging clandestine migration; a border management aiming at lifesaving and border security; development of a sounder asylum common policy; and establishment of a new policy in matter of legal migration by modernising and revising the "blue card" regime, by establishing some new priorities of the integration policies and by optimising the advantages of the migration policy for the aimed persons and the countries of origin. In September 2018, the Commission published a report on the progress made in the implementation of the European Agenda on migration, examining the progress and deficiencies in its implementation.
\end{abstract}

\section{KEY WORDS}

seasonal workers, admission, employer, short-stay visa, long-stay visa, worker permit

\section{INTRODUCTION}

Pursuant to art.79 para.1 of TFEU (Treaty on the Functioning of European Union) ' 'The Union shall develop a common immigration policy aimed at ensuring, at all stages, the efficient management of migration flows, fair treatment of third-country nationals residing legally in Member States, and the prevention of, and enhanced measures to combat, illegal immigration and trafficking in human beings”.

The adequate management of migration flows involves the guarantee of a fair treatment of third-country nationals lawfully residing in Member States, so, the European Union, by regulating some secondary union rules, aims at establishing a uniform level of rights and obligations for legal immigrants, similar to that of EU citizens.

The Lisbon Treaty also stated that the Union shares the competences in this field with the Member States, especially regarding the number of immigrants who are allowed the right to enter the territory of a Member State in order to seek work [article 79 para. (5) of TFEU]. Lastly, the European Court of Justice holds full jurisdiction on immigration and asylum at present. 
As for enforcement, at the European Union level, The Lisbon Treaty introduced the ordinary legislative procedure and the qualified majority voting, applying both to policies on clandestine migration and on legal immigration, granting the Parliament the statute of colawmaker in this field, on equal level with the Council. Nevertheless, the text of article 78 para. (3) of TFEU regulates an exception, thus, in case of a sudden inflow of nationals of third countries, the provisional measures are to be adopted only by the Council, but after consulting the European Parliament. The Union decision-making forum concluded, following the difficulties occurred in adopting a general disposition to fully cover the immigration of work labour into the EU, that the current approach consists in adopting some sectorial legislative rules for each category of immigrants in order to make a policy on legal migration within EU.

\section{PROVISIONS INCLUDED IN DIRECTIVE 2014/36/EU ON THE STATUTE OF THIRD-COUNTRY NATIONALS WHO ARE ON THE TERRITORYOF THE EUROPEAN UNIONFOR THE PURPOSE OF EMPLOYMENT AS SEASONAL WORKERS ${ }^{1}$}

Since 2008, they adopted a series of important directives on immigration, among which, Directive 2009/50/EC on the conditions of entry and residence of the third-country nationals in order to seek highly qualified jobs which is now under a revision process in the European Parliament and in the Council ${ }^{2}$; Directive (2011/98/EU) on the single residence permit, Directive 2014/36/EU on the conditions of entry and residence for the third-country nationals who want to work as seasonal workers, Directive 2014/66/EU on the conditions of entry and residence of the third-country nationals for a transfer within the same company, Directive (EU) 2016/801 on the conditions of entry and residence of the third-country nationals for research, studies, vocational training, voluntary services, student exchange programmes or educational projects and au-pair work, Directive 2003/109/EC of the Council, amended in 2011, on the statute of third-country nationals who are long-term residents in the European Union. At the above legal instruments, we can add Directive 2003/86/EC on the right to family reunification.

The Commission published in April 2014 a communication offering the Member States instructions on how to apply the EU competence about their integration. In July 2011, the Commission adopted the European Agenda on the integration of third-country nationals. More recently, in June 2016, the Commission presented an action plan including a policy framework and concrete measures to help Member States to integrate the approximately 20 million third-country nationals, legal residents within the Union.

The Union regulation established as a bench the efficient management of themigration flows for the specific category ofseasonal temporary migration and ensuring decent life and work conditionsfor seasonal workers, by establishing some correct and transparent rules on admission and stay, and by definingthe rights of seasonal workers, at the same time

\footnotetext{
${ }^{1}$ OG (government ordinance) no.25/2016 of amendment and addition of OG no.25/2014 on amendment and addition ofsome laws regarding the foreigners' regime in Romania, and OG no.194/2002 regarding the foreigners' regime in Romania, as republished with further amendments and additions, transposes the provisions of Directive 2014/36/EUn the conditions of entryand residence of third-country nationals for the purpose of employment as seasonal workers.

2Directive 2009/50/EC introduced the "European blue card”, a rapid procedure to issue a special residence and work permit for a period betweenone and four years. The blue card offers more attractive conditions tothirdcountry nationals in order to allow them the access to a highly qualified job within the Member States. The first reportregarding the application of this directive was published on22 may2014 and it identified a series of deficiencies. In June 2016, the Commission proposed a revision of the system, with less strict admission criteria, compulsory requirements concerning a minimum salary threshold/ a minimum duration of the labour agreement, improvement of the provisions regarding family reunification and elimination of parallel national systems.
} 


\section{EUROPEAN UNION LEGAL PROVISIONS ON THE ADMISSION OF THIRD-COUNTRY \\ NATIONALS FOR THE PURPOSE OF EMPLOYMENTAS SEASONAL WORKERS}

offeringincentives and guarantees to avoid exceeding the allowed period of temporary stay or to transform the temporarystay into long-term stay.

Actually, the directive analysed sets out the conditions of entry and residence of the thirdcountry nationals for the purpose of employment as seasonal workers, at the same time defining their rights. Within this directive, the following definitions apply:

a) "third country national" means any person who is not a citizen of the Union within the meaning of Article 20(1) TFEU;

b) "seasonal worker" means a third-country national who retains his or her principal place of residence in a third country and stays legally and temporarily in the territory of a Member State to carry out an activity dependent on the passing of the seasons, under one or more fixed-term work contracts concluded directly between that thirdcountry national and the employer established in that Member State;

c) "activity dependent on the passing of the seasons" means an activity that is tied to a certain time of the year by a recurring event or pattern of events linked to seasonal conditions during which required labour levels are significantly above those necessary for usually ongoing operations;

d) "single application procedure" means a procedure leading, on the basis of one application for the authorisation of a third-country national's stay and work in the territory of a Member State, to a decision on the application for a seasonal worker permit;

e) " short-stay visa" means an authorisation issued by a Member State as provided for in point (2)(a) of Article 2 of the Visa Code or issued in accordance with the national law of a Member State not applying the Schengen acquis in full;

f) " long-stay visa” means an authorisation issued by a Member State as provided for in Article 18 of the Schengen Implementing Convention or issued in accordance with the national law of a Member State not applying the Schengen acquis in full.

Specificities of work relationships.

The work relationships are established directly between third-country nationals and employers. However, where the national law of a Member State allows the admission of thirdcountry nationals as seasonal workers through employment or temporary work agencies established on its territory and which have a direct agreement with the seasonal worker, such agencies should not be excluded from the scope of this directive.

Classes of admissions.

We identify two classes of admissions, those not exceeding 90 days requiring short-term visas, and admissions exceeding 90 days requiring long-term visas.

The Union rule, by its directives, offers certain flexibility to Member States regarding the authorisations to be issued for admission (entry, stay and work) to seasonal workers. Through national regulations of transposing this directive, Member States ensures the easy access for applicants to the information concerning all justifying documents necessary to the application and the information concerning the entry and stay, including the rights and obligations and procedural guarantees of the seasonal worker.

Actually, for a stay not exceeding 90 days, Member States can choose to issue:

- a short-stay visa,

- a short-stay visa accompanied by a work permit in case the third-country national requests a visa pursuant to Regulation (EC) no. 539/2001.

Any admission application into a Member State, both for a stay not exceeding 90 days and for a stay exceeding 90 days, should be accompanied by: 


\section{Elise-Nicoleta Vâlcu}

a. a valid labour contract or, if otherwise provided for by national law or national administrative regulations, a binding job offer as a seasonal worker in the Member State concerned, from an employer established in that Member State, specifying: the place and type of work, the duration of employment; the remuneration; the working hours per week or month; the amount of any paid leave; the date of commencement of employment.

b. evidence of having or, if provided for by national law, having applied for, sickness insurance for all the risks normally covered for nationals of the Member State concerned.

c. evidence that the seasonal worker will have adequate accommodation or that adequate accommodation will be provided. In this regard, Article 20 of the Directive provides that Member States should make sure that seasonal workers benefit from accommodation that ensures an adequate standard of living. When accommodation is arranged by or through the employer, the rent should not be excessive compared to the seasonal worker's net remuneration and to the quality of such accommodation; the seasonal worker's rent should not be automatically deducted from the seasonal worker's wages; the employer should provide the seasonal worker with a rental agreement or an equivalent document specifying the rental conditions of the accommodation, and the employer should make sure that such accommodation meets the general health and safety standards in force in the Member State concerned.

For stays exceeding 90 days, member States can enforce by the implementation regulations, if any, the issue of one of the following authorisations:

- a long-term visa,

- a seasonal worker permit,

- a seasonal worker permit accompanied by a long-term visa, if the long-term visa is necessary to enter the territory pursuant to the national law.

In case a seasonal worker was admitted for a stay not exceeding 90 days and in case the Member State decided to extend the stay more than 90 days, the short-stay visa is replaced either by a long-stay visa or by a seasonal worker permit.

The third-country nationals who own a valid travel document and an authorisation in order to seek seasonal work, issued based on this directive by a Member State applying the Schengen acquis in full, are allowed to enter the territory of the Member State applying the Schengen acquis in full and to move freely on such territory, a period up to 90 days during any period of 180 days, in accordance with the Schengen Border Code and with article 21 of Convention of enforcement of the Schengen Agreement on $14^{\text {th }}$ June 1985 between the governments of the states from the Benelux Economic Union, of the Federal Republic of Germany and of the French Republic, on the gradual elimination of the controls at the common borders (Convention of enforcement of Schengen agreement).

Also, Member Statescan impose thefollowing requirements:

1. the period of validity to exceed the intended duration of stay by a maximum of three months;

2. the travel document to have been issued within the last 10 years; and

3. the travel document to contain at least two blank pages.

Pursuant to art.8, the Member States shall reject, if any, an application for authorisation for the purpose of seasonal work where:

- the documents presented for employment were fraudulently acquired, or falsified, or tampered with; 
- if the vacancy in question could be occupied by the nationals of the Member State concerned or by other Union citizens, or by other third-country nationals lawfullyresiding in that Member State;

- the employer has been sanctioned in accordance with national law for undeclared work and/or illegal employment

- the employer's business is being or has been wound up under national insolvency laws or no economic activity is taking place;

- the employer has failed to meet its legal obligations regarding social security, taxation, labour rights, working conditions or terms of employment, as provided for in applicable law and/or collective agreements

- within the 12 months immediately preceding the date of the application, the employer has abolished a full-time position in order to create the vacancy that the employer is trying to fill by use of this Directive;

- the third-country national has not fulfilled his or her obligations coming from a prior decision on admission as a seasonal worker.

Duration and extension of duration of stay.

Article 14 states that Member States, by the implementation regulations, shall determine a maximum period of stay for seasonal workers which shall be not less than five months and not more than nine months in any 12-month period. After the expiry of that period, the thirdcountry national shall leave the territory of the Member State unless:

i. the Member State concerned has issued a residence permit under national or Union law for purposes other than seasonal work.

ii. the seasonal workers extend their agreement with the same employer.

iii. the seasonal workers are to be employed by another employer.

Refuseto extend the stay.

The Member States can refuse the extension of the stay or the renewal of the authorisation for the purpose of seasonal work where:

a) the vacancy in question could be occupied by third-country nationals of the member State concerned or by other Union citizens;

b) the vacancy could be occupied by third-country nationals lawfully residing in that Member State;

c) the maximum duration of stay has been reached;

d) if the third-country national applies for international protection under Directive 2011/95/EU or if the third-country national applies for protection in accordance with national law, international obligations or practice of the Member State concerned

Facilitation of re-entry.

Article 16 from the Union regulation states that the Member States shall facilitate re-entry of third-country nationals who were admitted to that Member State as seasonal workers at least once within the previous five years, and who fully respected the conditions applicable to seasonal workers under this Directive during each of their stay

I. The facilitation referred above may include one or more measures such as:the issuing of several seasonal worker permits in a single administrative act;

II. an accelerated procedure leading to a decision on the application for a seasonal worker permit or a long-stay visa;

III. priority in examining applications for admission as a seasonal worker, including taking into account previous admissions when deciding on applications with regard to the exhaustion of volumes of admission. 


\section{Elise-Nicoleta Vâlcu}

Sanctions against employers. The Member States provide sanctions against employers who have not fulfilled their obligations under this Directive. Thus, in case of invoking some reasons attributable to the employer, and therefore the authorisation for the purpose of seasonal work is withdrawn, the employer shall be liable to pay compensation to the seasonal worker in accordance with procedures under national law ${ }^{3}$. Any liability shall cover any outstanding obligations which the employer would have to respect if the authorisation for the purpose of seasonal work had not been withdrawn.

Limitations in recognizing the rights of seasonal workers.

As for the temporary character of the stay of the seasonal workers, we consider that Member States can exclude from enforcement some aspects aiming at family reunification, family benefits and unemployment benefits, from the right to an equal treatment of seasonal workers with the nationals of the Member States concerned and can restrict the right to an equal treatment regarding education and vocational training, as well as fiscal benefits.

Also, this directive shall not grant more rights than those already granted by the existing European Union legislation in case of third-country nationals having cross-border interests between the Member States.

\section{CONCLUSIONS}

We consider that maintaining a coherent Union policy on immigration is imposed, that should make available the opportunities created by the phenomenon of legal immigration, and, at the same time, should solve the problems caused by illegal immigration. This policy should take into account the priorities and need of each Member State and encourage the integration of the citizens coming from outside the European Union into the communities receiving them.

Also, we have to mention that the European Union endeavours to create partnerships with the countries of origin and with transited countries in order to organize more efficiently the legal immigration and to fight the illegal one, to improve the ratio between migration and development, to consolidate the rightful state and to promote the compliance with the fundamental rights in such these countries.

The seasonal workers coming from outside the European Union fall into the category of third-country nationals who are lawfully residing within it. However, the temporary character of their stay does not grant them the social rights fully recognised for the outsidethe-EU nationals who are on the territory of the Union under other conditions than those regulated by this directive. We cannot help noticing that, by this regulation, the Union lawmaker "took care" of the recognition and guarantee of a minimal sets of rights offering decent living conditions, protection against employers' abuses.

\section{BIBLIOGRAPHY}

Directive 2014/36/EUof the European Parliament and of the Councilon 26 February 2014 on the conditions of entry and stay of the third-country nationals for the purpose of employment as seasonal workers;

Directive 2011/95/EUof the European Parliament and of the Council on 13 December 2011 on the standardsfor the qualification of third-country nationals or stateless persons as beneficiaries of international protection, for a uniform status for refugees or for persons eligible for subsidiary protection, and for the content of the protection granted;

Regulation (EC) no. 810/2009 of the European Parliament and of the Councilon13 July 2009 establishing a Community Codeon Visas (Visa Code);

${ }^{3}$ art.17 para. 2 
Directive 2009/52/ECof the European Parliament and of the Council on 18 June 2009 providing for minimum standards on sanctions and measures against employers of illegally staying third-country nationals. 